\title{
The Influence of D-Asparagine on the Glial Cicatrix Formation in Experimental Spinal Stroke
}

\author{
Chitanava Tamara, Egiev Ivan, Chechelian Valerii, Dzhopua Maksim, Trofimenko Artem, \\ Zanin Sergey, Turovaya Alla, Kade Azamat
}

Department of Common and Clinical Pathophysiology, Federal State Budget Educational Institution of Higher Education "Kuban State Medical University" of the Ministry of Health of the Russian Federation, Krasnodar, Russia

\section{Email address:}

Chitanava.tamara@yandex.ru (C. Tamara), ivan.egiev@mail.ru (E. Ivan), Valera.chechelian2013@yandex.ru (C. Valerii), 9912210@mail.ru (D. Maksim), artemtrofimenko@mail.ru (T. Artem), zanin77@mail.ru (Z. Sergey), alla_turovaya@rambler.ru (T. Alla), akh_kade@mail.ru (K. Azamat)

\section{To cite this article:}

Chitanava Tamara, Egiev Ivan, Chechelian Valerii, Dzhopua Maksim, Trofimenko Artem, Zanin Sergey, Turovaya Alla, Kade Azamat. The Influence of D-Asparagine on the Glial Cicatrix Formation in Experimental Spinal Stroke. American Journal of Clinical and Experimental Medicine. Vol. 5, No. 3, 2017, pp. 93-96. doi: 10.11648/j.ajcem.20170503.15

Received: February 27, 2017; Accepted: April 5, 2017; Published: May 9, 2017

\begin{abstract}
The effect of D-asparagine administered exogenously on the glial cicatrix formation was studied in experimental spinal stroke model in rats, which was conducted by photothrombosis of vessels in thoracic spinal cord. The experiments were carried out on three groups of animals: group №1 $(\mathrm{n}=20)$ which was a control group; №2 group $(\mathrm{n}=20)$ which included rats with spinal stroke model; group №3 $(\mathrm{n}=20)$ included rats with spinal stroke model that D-Asparagine was administered from $3^{\text {rd }}$ to $6^{\text {th }}$ day of the experiment, with the dosage $21.7 \mathrm{mg} / \mathrm{kg}$ for the course of treatment. According to the analysis results of spinal cord micropreparations it is obvious that the density of cell distribution in the spinal cord slices in rats of group №3 (Dasparagine with the dosage $21,7 \mathrm{mg} / \mathrm{kg}$ for the course of treatment) is three times lower in comparison with the same index of the rats from group №2 (without $D$-asparagine), $(\mathrm{p} \leq 0,01)$. Thus, the density of cell distribution in photothrombosis lesions of spinal cord vessels on micropreparations from group №3 (D-asparagine with the dosage $21,7 \mathrm{mg} / \mathrm{kg}$ for the course of treatment) is close to the value from group №1 (control), which means that statistically significant differences between the amount of cells in group №1 (control) and group №3 (administered by D-asparagine) have not been identified ( $\mathrm{p} \geq 0,01$ ).
\end{abstract}

Keywords: D-Asparagine, Glial Cicatrix, Spinal Cord Injury, Photothrombosis, Micropreparations, Rats

\section{Introduction}

Acute spinal cord injury is one of the most actual problems of modern medicine, which is caused by serious neurological disorders, great number of complications accompanied by the damage of spinal cord and extremely low rehabilitation capacity, which leads to the high level of disability in these patients [3]. A key reason for poor prognosis (in terms of the recovery of neurological deficit) in patients with acute spinal cord injury is the formation of glial cicatrix in the area of spinal cord lesion $[1,2]$. Glial cicatrix is both a mechanical and molecular (the synthesis of substances which inhibit the growth of axons) barrier for sprouting of axons distal to the lesion $[1,2]$.

The development of medicines able to inhibit the formation of glial cicatrix is the most perspective direction of modern medical science, due to the fact that these medications are able to enhance the rehabilitation capacity of this category of patients $[1,2]$. D-asparagine was suggested as a means capable to inhibit glial proliferation in the photothrombosis lesion [6].

$\mathrm{D}$-asparagine is produced in mammals in small quantities which have a range of physiological effects, and therefore, systems of neutralization are well developed in mature cells [10]. At the same time it is known that the deficiency of Dasparagine racemase causes inhibition of proliferation of immature cells $[6,10]$.

Antiproliferative effects of D-asparagine can be compared with the effects of cytotoxic therapy, but unlike cytostatic agents severe side effects have not been identified when using D-asparagine [5]. 
The AIM of this research is to study the influence of DAsparagine on glial transformation of spinal cord in the experiment in rats with the model of spinal stroke.

\section{Materials and Methods}

The study was carried out in the laboratory of the Department of general and clinical pathophysiology at Kuban state medical university. The experiments were carried out on 60 white male rats with average weight $346 \pm 75 \mathrm{gr}$. Animal housing and experiments were done according with the requirements of Ministry of Health of the Russian Federation dated from 04.01.2016 №199, as well as with international rules «Guide for the care and use of the laboratory animals».

Groups characteristics: group №1 included 20 (control) rats, whose spinal cord was used as a control sample; group №2 (compared) included 20 rats which were exposed to photothrombosis of vessels of thoracic spinal cord; group №3: (experimental) included 20 rats which were exposed to spinal stroke and were treated by D-Asparagine from the $3^{\text {rd }}$ to the $6^{\text {th }}$ day of the experiment. Euthanasia and extraction of the injured part of spinal cord in rats were made on the $17^{\text {th }}$ day of the experiment.

Intravenous injection (into tail veins) with $0.5 \%$ Dasparagine solution made on water for injections were administered to rats from group №3. Course dose of Dasparagine was $21.7 \mathrm{mg} / \mathrm{kg}$.

The modeling of spinal stroke was carried out in accordance with the modified method by M. Von Euler by photothrombosis of vessels of thoracic spinal cord with the laser (wavelength $514 \mathrm{~nm}$ ). Erythrosine was used as photosensitizer; tranexamic acid was used to inhibit fibrinolysis [6, 9]. During the operation zoletil-xylazine anesthesia was applied [4].

Rats were euthanized on $17^{\text {th }}$ day of the experiment. Sampling of spinal cord was made by its ejection with PBS introduced through the cannula of the syringe $10 \mathrm{ml}$, inserted in the lumbar spine [7]. After removing spinal cord tissues were fixed in zinc-formalin retainer with zinc sulfate [8]. Then the produced samples were immersed into different kinds of isopropanol-mineral oil, with subsequent embedding with paraffin wax. The paraffin blocks were sliced by microtome MPS-2(USSR) with the thickness of 10 micron. Micropreparations were colored with hematoxylin - eosin.

For taking photographs of micropreparations microscope «Mikmed-5» (Russia) and eyepiece camera Levenhuk-230 (USA) were used. Photo editor GIMP2 was used to analyze samples. Using the tool "grid" the amount of cells was counted. Grid cells were preliminary calibrated with the help of micrometer.

The processing of statistical data obtained was carried out with the help of software «Statistica 10 version» made by Stat Soft Inc. After the statistical processing the obtained results were expressed with the help of median (Me) using the 75 and 25 percentiles (p25 and p75). Also the confidence interval 95 was determined. The Shapiro-Wilk criterium was applied to test hypothesis about Gaussian distribution parameters in the studied groups. Due to the fact that the distribution of the values of parameters in the studied groups were different from normal, their comparison was carried out using non-parametric criterium by Kolmogorov-Smirnov, with the level of significance $* \mathrm{p} \leq 0,05$.

\section{The Results}

Death of animals during the experiment has not been reported. While examining the micropreparations of spinal cord taken from rats in group №1 (control), longitudinal fascicles of conducting tracts can clearly be seen in the area of incision. (Figure 1, 2).

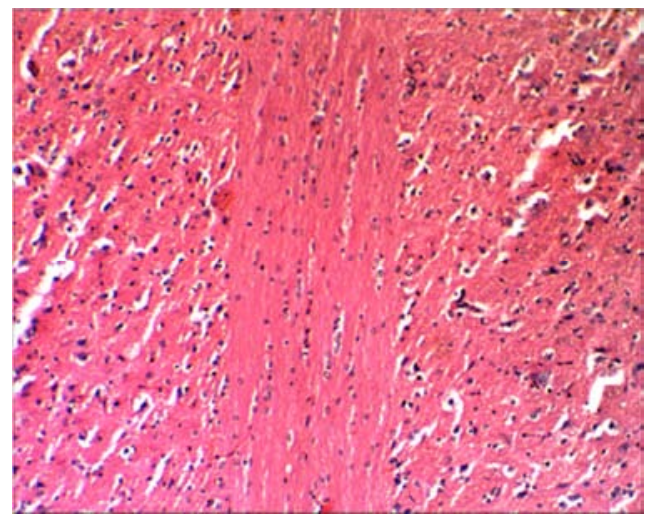

Figure 1. Pathways to a longitudinal spinal cord sections, the X100. Coloring was performed with hematoxylin-eosin.

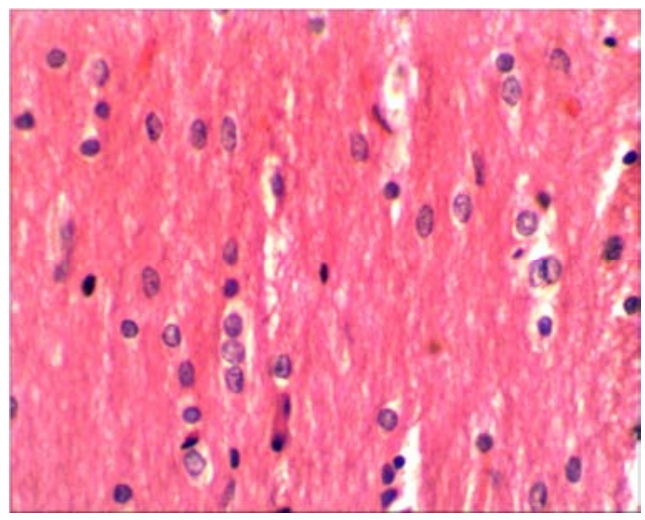

Figure 2. The nuclei of oligodendrocytes in the longitudinal spinal cord sections, X400. Coloring was performed with hematoxylin-eosin.

The phenomena of distinct spinal cord glial transformation were observed on micropreparations of longitudinal fascicles of conducting tracts taken from group of rats №2 on the $17^{\text {th }}$ day after the spinal stroke (without D-asparagine). The large cell nests of glial cells (presumably astrocytes) which form honeycomb structures were seen in area of conduction tracts. It testifies to the process of glial cicatrix formation in the area of photothrombosis of vessels of thoracic spinal cord. (Figure 3 and 4).

When comparing the cell amount in micropreparations in the area of photothrombosis of vessels of thoracic spinal cord taken from the groups №1 and №2, it was found out that the amount of glial cells had more than tripled $(p \leq 0.001)$ in 
group №2 by the $17^{\text {th }}$ day from the beginning of experiment (without usage of D-asparagine) which testified to the active process of glial transformation in the photothrombosis area "table 1".

Table 1. The amount of cells in the photothrombosis area of vessels in thoracic spinal cord on the $17^{\text {th }}$ day of the experiment.

\begin{tabular}{llll}
\hline & $\begin{array}{l}\text { Group \#1 } \\
\text { (control) }\end{array}$ & $\begin{array}{l}\text { Group \#2 } \\
\text { (comparison) }\end{array}$ & $\begin{array}{l}\text { Group \#3 } \\
\text { (experimental) }\end{array}$ \\
\hline Me & 3 & 9 & 3,5 \\
p75 & 5 & 13 & 6 \\
p25 & 3 & 8,5 & 2,5 \\
CI, 95 & $2,9-5,3$ & $7,7-14$ & $2,8-5,0$ \\
Kolmogorov- & - & $\mathrm{p} \leq 0,001$ & $\mathrm{p} \geq 0,01$ \\
Smirnov criterium & - & - & $\mathrm{p} \leq 0,01$ \\
\hline
\end{tabular}

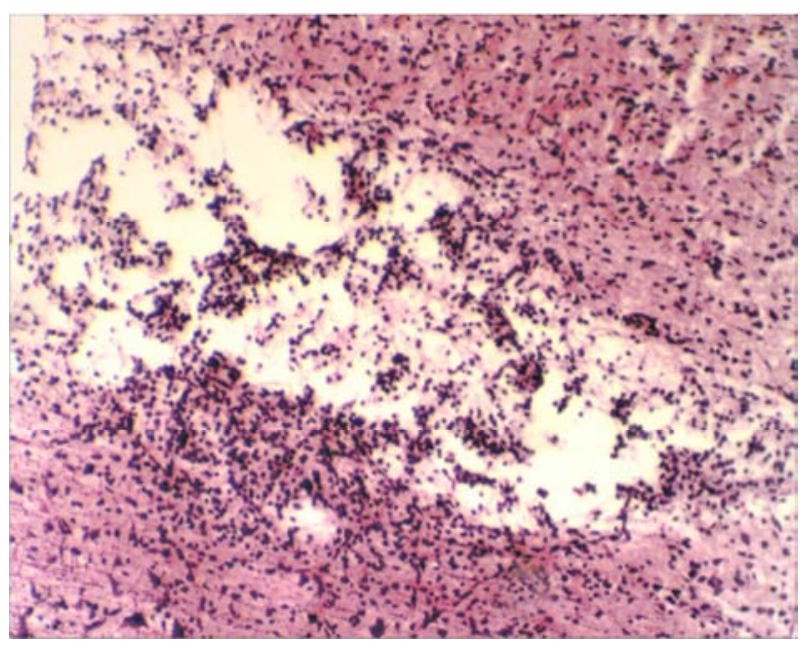

Figure 3. The glial transformation of spinal cord, X100. Coloring was performed with hematoxylin-eosin.

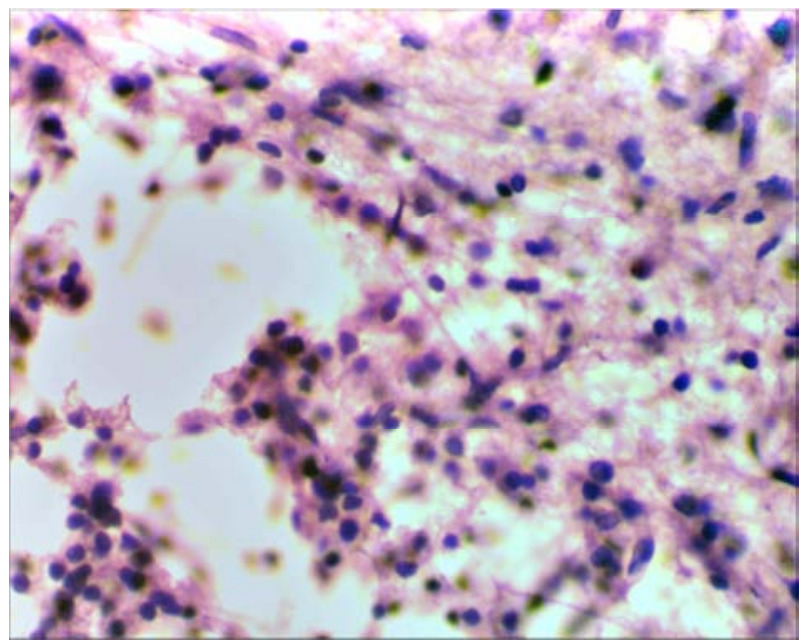

Figure 4. The glial transformation of spinal cord, X400. Coloring was performed with hematoxylin - eosin.

A small focus of gliosis was observed on micropreparations of longitudinal fascicles of conducting tracts taken from group of rats №3 on the $17^{\text {th }}$ day after the spinal stroke (D-asparagine used in the course dose 21,7 $\mathrm{mg} / \mathrm{kg}$ ) At the same time in the area of photothrombosis of vessels of thoracic spinal cord much smaller amount of glial cells could be seen in comparison with the micropreparations from the group №2 (without usage D-asparagine), only individual traced axons passing through the area glial cicatrix can be seen which testified to the effectiveness D-asparagine (Figure 5, 6).

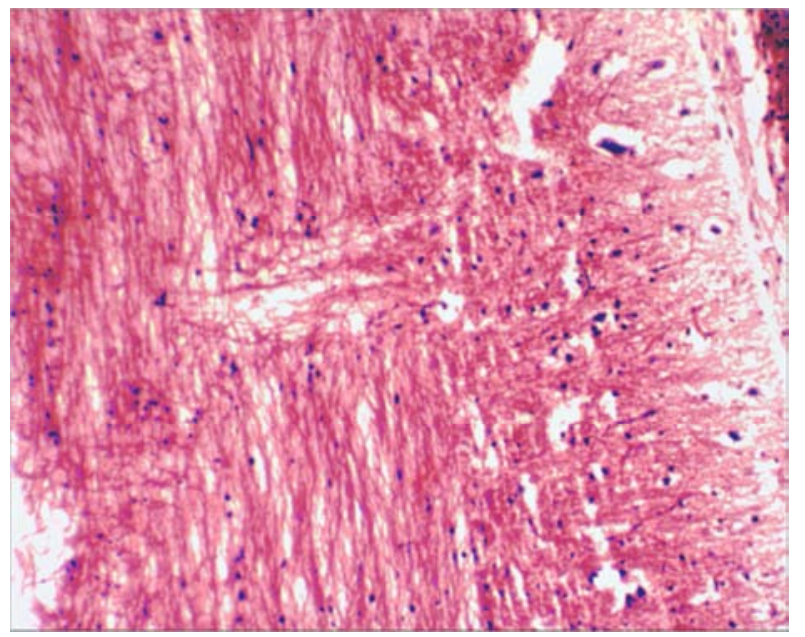

Figure 5. The area of gliosis in the spinal cord, X100. Coloring was performed with hematoxylin - eosin.

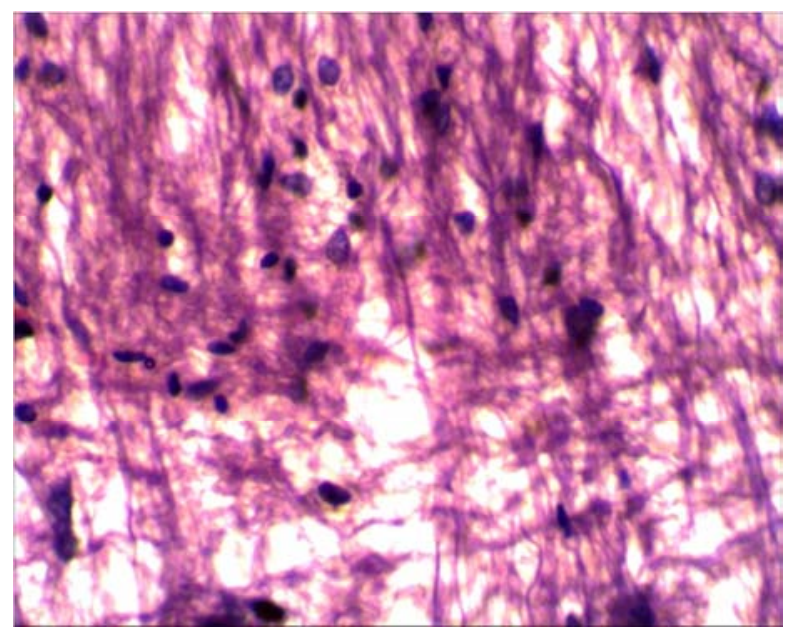

Figure 6. The area of gliosis in the spinal cord, X400. Coloring was performed with hematoxylin-eosin.

When comparing the amount of cells on micropreparations in the area of photothrombosis of vessels in thoracic spinal cord from group №2 (without usage of D-asparagine) and group №3 (D-asparagine used in the course dose 21, 7 $\mathrm{mg} / \mathrm{kg}$ ), considerable differences are seen. The density of glial cell distribution in the area of photothrombosis in micropreparations from group №3 (D-asparagine used in the course dose $21,7 \mathrm{mg} / \mathrm{kg})$ is three-times lower $(\mathrm{p} \leq 0.01)$ in comparison with the same index from group №2 (without usage of D-asparagine). Thus, the density of cell distribution in micropreparations from group №3 (D-asparagine used in the course dose $21,7 \mathrm{mg} / \mathrm{kg}$ ) is close to the value obtained in group №1 (control). There are no statistically significant differences between the amount of cells in group №1 (control) and group №3 (D-asparagine used in the course dose $217 \mathrm{mg} / \mathrm{kg})(\mathrm{p} \geq 0,01)$. 


\section{Conclusions}

In case of using erythrosine (as a photo-sensitizer) and tranexamic acid (as fibrinolysis inhibitor) together thoracic spinal cord vascular photothrombosis made by laser (wavelength $514 \mathrm{~nm}$ ) on the $17^{\text {th }}$ day from the beginning of the experiment can lead to severe glial transformation in the involved area of spinal cord. Intravenous administration of $0.5 \%$ solution of D-asparagine in the course dose of 21.7 $\mathrm{mg} / \mathrm{kg}$, from $3^{\text {rd }}$ to $6^{\text {th }}$ days from the beginning of the experimental spinal stroke is accompanied by significantly less severe process of glial transformation, according to histological examination of micropreparations of spinal cord carried out on the $17^{\text {th }}$ day of the experiment. Therefore, further study of D-asparagine is prospective since it can significantly increase the rehabilitation capacity in patients with acute spinal cord injury.

\section{References}

[1] Ber M. Neuroprotection: models, mechanisms, therapy/ M. Ber. - M.:Binom. Laboratory of knowledge. - 2011. - 429 pages.

[2] Bryukhovetskiy I. S., Dyuizen I. V. Morfochemical charachteristic of the spinal cord of rats after the transplantation of polymer collagen neuromatrix "Sferogel E" TM with the incorporated parietal neuroepithelial cells // Genes and cells. - 2008. - №2. $-57-62$ pages.
[3] Morozov I. N., Mlyavikx S. G. Epidemiology of spinal cord injury (review) // Medical Almanac. - 2011. - №4. - 157-159 pages.

[4] Trofimenko A. I. $\beta$ - endorphin and cytokine profile in dynamics of experimental ischemic stroke // Modern problems of science and education - 2014. - №6. - 1125 page.

[5] Fadeeva V. E. Investigation the safety of usage D-asparagine in experimental model of spinal stroke in rats // In: Medical science and Public health. - 2016. - 73 - 74 pages.

[6] Chitanava T. V. The influence of D-asparagine on the formation of glial cicatrix in experimental spinal stroke in rats // In: Medical science and Public health. - 2016. - 37 - 39 pages.

[7] Kennedy H. S. A method for removing the brain and spinal cord as one unit from adult mice and rats // Lab Anim (NY). 2011. - Feb; 40(2):53-7. doi: 10.1038/laban 0211-53.

[8] Kierman J. A. Histological and histochemical methods. Theory and practice. - London: Scion Publishing Ltd. - 2008. -606 page.

[9] Von Euler M. Morphological characterization of the evolving rat spinal cord injury after photochemically induced ischemia // Acta Neuropathol. - 1997 Sep; 94(3). - 232-239 pages.

[10] Wolosker H, D'Aniello A, Snyder SH. D-aspartate disposition in neuronal and endocrine tissues: ontogeny, biosynthesis and release // Neuroscience. -2000 . - 100(1). -183 -189 pages. 